Joanna Roś

\title{
FATUM I ABSURD. \\ INSPIRACJA TRAGEDIĄ GRECKA W TWÓRCZOŚCI ALBERTA CAMUSA
}

Na łamach Notatników francusko-algierski pisarz Albert Camus często dzieli się swoimi przemyśleniami dotyczącymi świata antycznego. Dzięki temu wnikliwi badacze twórczości pisarza z powodzeniem mogą odnajdywać odwołania do charakterystycznych prawideł tego świata w jego twórczości stricte literackiej.

W Notatnikach czytamy:

W dramacie antycznym zawsze płaci ten, kto ma rację. Prometeusz, Edyp, Orestes, itd., ale to nie ma znaczenia. Tak czy inaczej, z karą lub bez, wszyscy kończą w piekle. Nie ma ani nagrody, ani kary. Stąd dla naszych oczu, zaćmionych wiekami wypaczeń chrześcijańskich, bezinteresowny charakter tych dramatów - ich patos także ${ }^{1}$.

Jak widzimy, Camus nie jest zniechęcony brutalnością ani bezwzględnością dramatu antycznego. Wprost przeciwnie - bezinte-

${ }^{1}$ A. Camus, Eseje, przeł. J. Guze, Państwowy Instytut Wydawniczy, Warszawa, s. 481. 
resowność dramatu, o której pisze, jest dla niego nie tylko godna uwagi, ale i inspirująca.

Wielu badaczy starożytnej Grecji podkreśla, że w świecie antycznym bardziej interesująca od komedii była ostatecznie tragedia grecka, ponieważ analizowała mity, dotyczące cierpienia i unikania go. Ludzie byli nią zachwyceni, gdyż godziła zasadniczą sprzeczność losu ludzkiego, ukazując, że cierpienie jest nie tylko tym, co buduje mur pomiędzy Bogiem a człowiekiem, ale także tym, co pozwala doświadczyć boskości ${ }^{2}$. Dramat wyłonił się z misteriów, a należy pamiętać, że misteria odprawiano na cześć bóstwa. Dramaturg pełni rolę tego, który tłumaczy tajemnicę inności, obcości bytu i człowieka. Według Zygmunta Kubiaka, poeta grecki był kimś w rodzaju proroka, przynajmniej w tym znaczeniu, że wybierał - spośród mitycznych treści - te, które w duchowej medytacji uznawał za najbliższe prawdy, jakiej poszukiwał’ Dramat jest więc takim przywołaniem mitu, które stawia uczestników misteriów wobec tajemnicy. To ją dramaturg chce rozważyć, sądzi, że dla ludzi jest najistotniejsza. Jak pisał Arystoteles:

Jest tedy tragedia naśladowczym przedstawieniem czynności (akcji poważnej, skończonej w sobie, o określonej wielkości, przedstawieniem wyrażającym w mowie ozdobnej, [...] przy pomocy osób działających, a nie przez opowiadanie, i dokonującym przez wzbudzenie litości i trwogi właściwego sobie oczyszczenia tego rodzaju afektów) $)^{4}$.

${ }^{2}$ A. Korczak, Mądrość starożytnych Greków, Miniatura, Kraków 2007, s. 37.

${ }^{3}$ Zob. tamże, s. 380.

${ }^{4}$ Arystoteles, Poetyka, [w:] Trzy poetyki klasyczne: Arystoteles-Horacy-PseudoLongines, przeł. T. Sinko, Ossolineum, Wrocław 1951, s. 13. 
Arystotelesowską miarą doskonałości tragedii jest jej skuteczność, czyli moc oddziaływania na uczucia widzów.

W tragedii greckiej podejmowano temat swoistej sakralności czasu, ale nie chodziło tu o czas jako ogólne pojęcie, ale czas każdego indywidualnego życia, „odmierzanego od narodzin do śmierci". Ponadto, oprócz tematu upływającego czasu poszczególnego istnienia, tragedia mówiła zawsze o „wyjściu poza ludzką formę, ludzką miarę wszystkich rzeczy ${ }^{5 "}$, co doprowadziło do jej ostatecznego triumfu.

Tragedia powstaje, kiedy każda z przeciwstawnych sobie sił jest jednako uprawniona. Stąd tragedia słaba: gdzie działają siły nieuprawnione. Stąd wielka tragedia: która uprawomocnia wszystko ${ }^{6}$.

Camusa szczególnie interesuje właśnie owo wyjście poza ludzką miarę.

\section{EDYP, CZYLI FORMUŁA ZWYCIĘSTWA ABSURDALNEGO}

Camus w swojej twórczości często podejmuje temat Edypa, analizując na podstawie dramatu Sofoklesa prawidła rządzące całą tragedią grecką. Edyp, według pisarza, jest posłuszny przeznaczeniu, dopóki nie dowiaduje się prawdy o swoim pochodzeniu. Tragedia bohatera nie jest odwieczna, pojawia się dopiero w momencie, ,kiedy Edyp wie”. Przede wszystkim jednak w historii Edypa odnajduje Camus prawdziwą „formułę zwycięstwa absurdalnego ${ }^{7 ”}$, gdy w ostatniej części dzieła Sofoklesa oślepiony

\footnotetext{
${ }^{5}$ A. Korczak, Mądrość..., s. 36.

${ }^{6}$ A. Camus, Eseje..., s. 514.

${ }^{7}$ Tamże, s. 197.
} 
bohater, pozbawiony złudzeń co do swojej przyszłości, wyznaje: „Choć tak bardzo zostałem doświadczony, wiek mój podeszły i dusza moja znająca wielkość mówią mi, że wszystko jest dobre" Francuski pisarz jest zafascynowany sposobem, w jaki wybrzmiewa to pamiętne wyznanie Edypa. Są to bowiem słowa człowieka, który stracił wszystko - szacunek wiernych, miłość rodziny, a ich miejsce musiał zastąpić przerażającą akceptacją samego siebie, takiego, jakim stał się po odkryciu prawdy.

Jak pisze Jan Kott, rozważając pojęcie absurdu w tragedii greckiej, dla Camusa: „Absurd tylko tak długo znaczy, dopóki się na niego nie przystaje" Camus zupełnie na nowo interpretuje te znaczące słowa Edypa. Dla francuskiego pisarza świadczą one o pogardliwym pogodzeniu się z losem, zgodnie z tezą że „nie ma takiego losu, którego nie przezwycięży pogarda ${ }^{10}$. Camus nie przyjmuje, że te wielkie słowa, pochodzące $\mathrm{z}$ ostatniego utworu Sofoklesa, przeczą, jakoby tragedia grecka miała charakter tylko i wyłącznie fatumiczny, chociaż przez historyków literatury oraz licznych interpretatorów uznawany jest za klasyczny dramat łaski, przełomowy względem pozostałych części tryptyku ${ }^{11}$. Według Camusa, Edyp otrzymuje niezwykłą lekcję - od teraz los bohatera może być określany tylko przez niego samego. Jednak czy Edyp jest tragiczny za sprawą wydarzeń, w których uczestniczył? Czy może o jego tragiczności stanowi coś zgoła innego?

${ }^{8}$ Tamże, s. 514. Zob. też Edyp w Kolonos Sofoklesa.

${ }^{9}$ J. Kott, Tragedia grecka i absurd, [w:] tenże, Zjadanie bogów, Wydawnictwo Literackie, Kraków 1986, s. 273.

${ }^{10}$ A. Camus, Mit Syzyfa i inne eseje, Muza, Warszawa 2004, s. 167.

${ }^{11} \mathrm{~K}$. Samsel, Afuzja $i$ wolność. Studium o Nieporozumieniu i Niemych Alberta Camusa, „Tekstualia” 2001, nr 1 (24), http://www.tekstualia.pl/index.php?DZIAL= teksty\&ID=602 (dostęp: 15 IX 2012). 
Wybitny badacz teatralny Jan Kott uważa, za Albertem Camusem, że to wcale nie w losach Edypa tkwi jego tragedia; nie jest tragiczny człowiek, ale świat „w którym synowi zapowiedziano z góry, ze zabije ojca i będzie spał z matką." A więc o tragedii Edypa świadczy dopiero cała historia, którą poznajemy dzięki Sofoklesowi, po kolei - Edyp, któremu udaje się rozwiązać zagadkę Sfinksa, aby po latach miał dowiedzieć się, że jest przy tym ojcobójcą i kazirodcą, a także przede wszystkim Edyp, jako oślepiony starzec, czekający już tylko na własną śmierć, aby wybawić od plagi ukochane Ateny. Simone Weil pisała:

Kto nie wie, jak bardzo zmienność losu i prawa konieczności są zdolne uzależnić każdą ludzką istotę, nie potrafi ludzi, których przypadek oddzielił od niego przepaścią, traktować jak sobie podobnych ani też kochać ich jak siebie samego ${ }^{12}$.

Dramat więc to doświadczenie mówiące, że losy nie toczą się oddzielnie, lecz zazębiają się i stają się całością. Jak sądziła Weil, Grecy wiedzieli, że ludzie marnieją, pozbawieni tego doświadczenia.

A jednak, Camus nie nazwałby Edypa kozłem ofiarnym, choć na pewno widział $\mathrm{w}$ nim swoistą mediację między cierpieniem, którego nic nie może usprawiedliwić, a mitem, który może usprawiedliwić wszystko. Autor wiedział, że tragedia nie istnieje bez mitu, o wiele jednak bardziej pragnął zauważyć, że tragedia mitowi zaprzecza. $\mathrm{O}$ ile $\mathrm{w}$ micie zawsze występuje mediacja pomiędzy człowiekiem, a panującymi nad nim siłami, o tyle morał tragedii zawsze głosi, że „mediacja jest niemożliwa”. Zawsze popycha to bohaterów do zmiany spojrzenia na istotę losu człowieka. I tak choćby Ajaks w blasku słońca zabija się mieczem, a Edyp pozbawia się wzroku, „żeby swój los uczynić widzialnym”.

\footnotetext{
${ }^{12}$ S. Weil, Iliada, czyli poemat o sile, przeł. A. Oledzka-Frybesowa, „Res Publica Nowa" 1997, nr 6 (105), s. 66.
} 
„Camus ma rację - wyznaje Jan Kott - nie jest absurdem, że Edyp spał z własną matką i zabił swego ojca, absurdem jest, że to było konieczne". Absurd ten potęguje jeszcze fakt, że o możliwości takiego zdarzenia został uprzedzony zarówno Lajos jak i Edyp. Najbardziej absurdalny jest jednak fakt, że ani bogowie, ani demony nie są odpowiedzialne za zaplanowanie tak okrutnych wydarzeń. W ten sposób tragedia Edypa jest prawdopodobnie najbardziej wstrząsającą wykładnią problematyki determinizmu i wolnej woli w całym świecie antycznym. Nic dziwnego, że zainteresował się nią Camus, skoro los człowieka został w niej przedstawiony jako gra człowieka z automatem, który musi wygraćc ${ }^{13}$. Pozornie gracze mają równe szanse, ale Edyp musi przegrać. Już Arystoteles zwracał uwagę na "taktykę absurdu” wpisaną w tragedię grecką, uznając, że Król Edyp Sofoklesa jest czymś w rodzaju apogeum owej sytuacji. Uważał, że:

\begin{abstract}
Perypetia jest to zmiana biegu wydarzeń w kierunku przeciwnym intencjom działania postaci [...]. Ma to miejsce w Królu Edypie, gdy przybywa poseł, który chce pocieszyć Edypa i uwolnić go od lęku przed związkiem z matką, lecz skoro wyjawia jego prawdziwe pochodzenie, sprawia, że skutek jest przeciwny ${ }^{14}$.
\end{abstract}

Na łamach Notatników Camus bardzo obrazowo wyjaśnia jeszcze jeden paradoks postaci Edypa. Otóż bohater zwyciężył Sfinksa, ponieważ bardzo dobrze znał naturę ludzką, a przecież to ten sam człowiek został brutalnie potraktowany przez bezlitosny los i jego ślepą logikę ${ }^{15}$. A jednak Edyp nie zgodzi się $\mathrm{z}$ absurdem i będzie

${ }^{13}$ Zob. J. Kott, Tragedia..., s. 279.

${ }^{14}$ Arystoteles, Poetyka, DeAgostini/Ossolineum, Wrocław 2006, s. 16-19.

${ }^{15}$ Zob. A. Camus, Notatniki 1935-1959, przeł. J. Guze, Wydawnictwo Krąg, Warszawa 1994, s. 64 . 
musiał uczynić jakiś gest na znak oporu przeciw brutalnemu światu. Wykłuje sobie oczy i nigdy nie zgodzi się absurdem, nawet wbrew sobie, nie przyzna, że jest winny. I będzie żył, aby ze swojego życia uczynić świadectwo absurdu. Dla pisarza porażka bohatera - taka, jakiej doświadcza Edyp - świadczy o wielkości człowieka, ponieważ „czasem można jeszcze nadać sens klęsce. I to jest ta rozpacz pełna nadziei, o której pisał Camus"16. To tutaj Edyp jest odbiciem camusowego Syzyfa.

Pisarz wybiera Sofoklesa, ponieważ jego tragedie są pełne konfliktów i sporów o właściwe postępowanie. Tragik wierzy w wyjątkowe znaczenie istnienia człowieka, w jego, często ukrytą wielkość. Przedstawia bohaterów wyjątkowo silnych, dumnych, nawet jeśli odrzuca ich społeczeństwo, nawet kiedy mogą się wydawać zabawkami bogów. U Sofoklesa sensem i znaczeniem czynów ludzkich są same motywy, jakie nimi kierują, same sposoby działania. Tragiczność u Sofoklesa wyraża się w pewnym ideale człowieka, który realizują jego bohaterowie ${ }^{17}$.

Dla Camusa tylko człowiek nowożytny, ponieważ czuje się samoistny, niezależny od wyższych sił, może oceniać świat i się na niego nie zgadzać. Camus jednak wcale nie zapomina, że „dla Greka epoki mitycznej absurd nie jest absurdalny, bo jest językiem bogów", jest jedynym prawdziwym sposobem ujawniania się istnienia. Jest stale zadawaną, straszliwą zagadką. Jedynym, co mogłoby tu być absurdalne, to bunt nie-samoistnego człowieka wobec boskiego „absurdu”. To człowiek współczesny nie godzi się na z góry ustanowioną nierówność sił, na nieuchronność przegranej.

${ }^{16}$ J. Kott, Tragedia..., s. 280.

${ }^{17}$ Zob. J. de Romilly, Tragedia grecka, przeł. I. Sławińska, Wydawnictwo Naukowe PWN, Warszawa 1994, s. 77. 
Dlaczego więc Camus przedstawił Edypa jako tego, który wygłasza „formułę zwycięstwa absurdalnego"? Przecież Grekom samoistność ludzkiego istnienia była zupełnie obca, dla nich człowiek nie był „stroną jakiegoś sporu, w którym racje są porównywalne". Edyp, jak powiedzieliśmy, musiał przegrać. Otóż musimy z całą pewnością stwierdzić, że Grecy epoki archaicznej nie przeżywali dramatu losu Edypa w taki sposób, jak interpretuje go Camus, pisząc o „zwycięstwie absurdalnym”. ${ }^{18}$ Przypomnijmy - Edyp musiał zabić swego ojca i poślubić własną matkę, ponieważ taki właśnie był wyrok losu, jaki na niego spadł. Fatum, czyli los w micie greckim, nie ma nic wspólnego z wolą człowieka, a kiedy człowiek się buntuje, pogarsza jeszcze tragizm swojego położenia. Właśnie tutaj Camus odnalazł konotację pomiędzy fatum i absurdem, ponieważ absurd także nie może zostać pokonany siłą ludzkiej woli, a bunt skierowany przeciwko absurdowi nie wybawia od nieszczęść.

Fatum jest jednak nadludzkim (niebiańskim) wymiarem spraw ludzkich, nadludzką miarą ludzkiego życia. Absurd natomiast pozostaje zawsze w ludzkim (ziemskim) świecie, a jego nadludzkość wyraża się tylko w bezsilności człowieka wobec absurdu ${ }^{19}$.

\section{PROMETEUSZ, CZYLI BRAK MEDIACJI MIĘDZY NIEBEM A ZIEMIA}

Nie możemy zapomnieć o jeszcze jednym bohaterze antycznym, który dla Camusa stanowi symbol absurdu losu, którym jest Prometeusz.

${ }^{18}$ Zob. K. Samsel, Afuzja..., http://www.tekstualia.pl/index.php?DZIAL=teksty \&ID=602 (dostęp: 15 IX 2012).

${ }^{19}$ W. Szydłowska, Dżuma Alberta Camusa, Wydawnictwa Szkolne i Pedagogiczne, Warszawa 1998, s. 11. 
Tragedia Ajschylosa Prometeusz w okowach zaczyna się ukrzyżowaniem Prometeusza w górach kaukaskich, a kończy strąceniem w bohatera na dno piekieł, czyli do Tartaru. Prometeusz przeżywa swoją tragedię pomiędzy niebem a ziemią, ukazując swoją historią dzieje bogów i ludzi. Jednak kosmos, do którego zaliczają się bogowie i ludzie, dla Camusa nie jest jeszcze absurdalny $^{20}$. Absurd wchodzi na scenę dopiero w momencie, kiedy Prometeusz ofiaruje ludziom inteligencję i ślepą nadzieję, ponieważ „absurd - pisał Camus - rodzi się z porównania ludzkich potrzeb z nierozumnym milczeniem świata". Ponadto, Prometeusz nie jest pozbawiony wyboru. Jak sam przyznaje, dobrze zna przyszłość, więc dla ratowania siebie może ostrzec Zeusa i wyjawić mu, kim jest kobieta, mająca urodzić „syna silniejszego od ojca" Ale, jak pisze Jan Kott, Prometeusz nie chce rozmawiać z Bogiem, woli milczeć, aby nie zawierać kompromisu z kosmosem, w ten sposób stając się bohaterem absurdalnym ${ }^{21}$, ponieważ „absurd tylko tak długo znaczy, dopóki się na niego przystaje”.

Franz Kafka, ulubieniec Camusa, był prawdopodobnie pierwszym pisarzem, który interesował się problematyką absurdu w tragedii greckiej i wskazywał szczegółowo na jego elementy ${ }^{22}$. W jego twórczości odnajdujemy „aforyzm o Prometeuszu”. Kafka pisze, że znane są cztery legendy na temat Prometeusza. Wedle pierwszej, którą posłużył się Camus, bohater został przykuty do skały na Kaukazie, co stanowiło karę za zdradę bogów. Druga historia mówi o tym, że Prometeusz od uderzeń dziobów sępów zapadał się w skałę, dopóki się z nią nie złączył. Wedle trzeciej, zdrada Prometeusza po tysiącach lat została zapomniana, nie

\footnotetext{
${ }^{20}$ Zob. J. Kott, Tragedia..., s. 272.

${ }^{21}$ Tamże, s. 273.

${ }^{22}$ Tamże, s. 272.
} 
tylko przez bogów i orły, ale i samego Prometeusza. Wedle czwartej opowieści bogowie mieli już dosyć Prometeusza i pozwolili, aby zagoiły się jego rany ${ }^{23}$.

Jak w przypadku tragedii o Edypie, trylogia o Prometeuszu kończyła się niewątpliwie „historycznym kompromisem”, pojednaniem bogów i Prometeusza. Ale ponieważ z drugiej i ostatniej części zostały tylko fragmenty, w świadomości kulturowej Prometeusz zapisał się wyłącznie jako heroiczny buntownik, do końca niezłamany i do końca dzielny. W ten sposób „historia mitów nie jest mityczna i w tradycji kulturowej już zawsze będzie to postać, reprezentująca symbol braku «mediacji pomiędzy niebem a ziemią»" ". Ajschylos, twórca Prometeusza skowanego nie tylko przecież przekazywał mity, ale także, ponieważ był pisarzem i posługiwał się twórczą wyobraźnią, tworzył je.

W taki też sposób postać Prometeusza przedstawił Camus. Co bardzo istotne, dramat grecki dla autora Mitu Syzyfa i Człowieka zbuntowanego był czymś więcej, niż tylko rodzajem antycznej sztuki. Był wyrazem uniwersalnego doświadczenia, jakim jest okrucieństwo losu.

Bo tragedia żyje działaniem, implikuje heroizm. Tragedia zbudowana wokół pewnego czynu do spełnienia zakłada afirmację człowieka. Słowo „drama” znaczy działanie. Gdyż w tragedii walczy się. To wysiłek w kierunku dobra. A wszystko, co czyni człowiek, dobrego czy złego, okazuje się pełne konsekwencji. Już to samo dodaje sit ${ }^{25}$.

${ }^{23} \mathrm{~J}$. Kott, Góra i dót, albo o wieloznacznościach Prometeusza, [w:] tenże, Zjadanie..., s. 52.

${ }^{24}$ Tamże, s. 39.

${ }^{25} \mathrm{~J}$. de Romilly, Tragedia..., s. 161. 
Fatum i absurd. Inspiracja tragedia grecka...

Dla pisarza dramat stanowił swoistą mapę urządzenia świata z miejscem zaznaczonym dla człowieka i odmowy przez człowieka cierpieniu.

Camus wie, że w tragedii nawet człowiek, który jest „igraszką bogów", zachowuje godność, siłę i honor w swojej klęsce, a także to, że postaci wplątane w straszne historie, zachowują ujmującą wielkość, co dodaje wiary i odwagi. Prawdziwy heroizm, który uosabiają bohaterowie antyczni, wywołuje współczucie, co sprawia, że teatr tragiczny, choć niewątpliwie zatrważający, ma za zadanie wzmocnić człowieka.

Pisząc o funkcjach antycznej Grecji nie można zapominać, że istniała tam hierarchia wartości, zupełnie różna od tej, z którą spotykamy się w dzisiejszym świecie. Autorzy tragedii greckich, przedstawiając skomplikowane, lecz odważne i bohaterskie czyny bohaterów, wyznaczyli wzór najlepszej postawy, jaką człowiek może przyjąć w obliczu cierpienia i niedogodności losu. Tragedia była przede wszystkim przewodnikiem dla ludzi w obliczu trudnych sytuacji egzystencjalnych, dopiero potem uciechą estetyczną. Starożytni zdawali sobie sprawę z trudnej kondycji egzystencjalnej człowieka, w związku z czym pragnęli przygotować go do sytuacji, w której będzie musiał stawić czoło własnemu, niepomyślnemu losowi. Przygotować go tak, aby umiał zachować godność w obliczu cierpienia. $Z$ tego też powodu tragedia sięgała do głębi ludzkich lęków i pożądań. Pokazywała człowiekowi, co powinien zrobić, kiedy cierpienie opanuje jego życie ${ }^{26}$. Zmuszając do udziału w cierpieniach, powodowała egzystencjalny niepokój.

${ }^{26}$ M. Plisiecka, Współczesny człowiek wobec tragedii greckiej, według A. J. Fetsugiere'a, „Człowiek w kulturze” 1999, nr 12, s. 15, w internecie: http://www.gilson society.pl/app/download/5776861587/M.+Plisiecka,+Wsp\%C3\%B3\%C5\%82czesny +cZ\%C5\%82owiek+wobec+tragedii+greckiej+wed\%C5\%82ug+A.+J.+Festugiere\%27a,+s .+13-22.pdf (dostęp: 15 IX 2012). 
Nie wydaje się więc dziwne, że Camus, który tak często nawoływał do postaw moralnych, w swojej twórczości powołując się na liczne przykłady godności i heroizmu, interesuje się utworami dramatycznymi, jako tym rodzajem sztuki, który ma na celu wspomagać i wychowywać człowieka.

Co Camus chce pokazać współczesnemu człowiekowi na podstawie tragedii Edypa i Prometeusza? Przede wszystkim wskazuje, że bohaterowie dramatu Sofoklesa i sztuki Ajschylosa mogą uczyć współczesnego człowieka, jak zachować godność wobec nieszczęścia. Autor na łamach Notatników przywołuje słowa Nietzchego z jego dzieła Zmierzch bogów, które mówią, że ludzie najbardziej wzniośli i najbardziej odważni przeżywają największe tragedie, jednak, ponieważ życie stawia im bolesny opór, zachowują do niego wielki szacunek ${ }^{27}$. Camus ukuł nawet własną definicję tragedii greckiej:

Tragedia idealna [...] jest przede wszystkim napięciem, ponieważ jest przeciwstawieniem, w przymusowym bezruchu, dwóch potęg, z których każda ukrywa się pod podwójną maską dobra i zła ${ }^{28}$.

Figury Edypa i Prometeusza, których losami rządzą fatum i absurd, są dla francuskiego pisarza sposobem ukazania istoty człowieczeństwa.

\footnotetext{
${ }^{27}$ Zob. A. Camus, Notatniki..., s. 48.

${ }^{28}$ Zob. Literatura francuska. XIX i XX wiek, t. II, PWN, Warszawa 1980, s. 624.
} 


\title{
FATE AND ABSURD. THE INSPIRATION OF GREEK TRAGEDY IN THE WORKS OF ALBERT CAMUS
}

\author{
SUMMARY
}

The purpose of this article is to show that the Greek drama for Albert Camus was an expression of the universal experience of the cruelty of fate. Dramatic stories of Oedipus and Prometheus were for him a kind of map of the world with space selected for the man and his denial of suffering. Camus knows that in the tragedy even a man who is a "plaything of the gods", maintains strength and honor in his defeat, and that the hero embroiled in horror stories, preserves the dignity, which adds faith and courage. This is where Camus found the connotation between the concept of fate and absurd, because absurd can't be defeated by force of human will, a munity directed against absurd does not save the Man from misfortune.

\section{KEYWORDS}

absurd, fate, Greek drama, Greek tragedy, Oedipus, Prometheus, Camus A. 